\title{
PENGARUH KEBIJAKAN UTANG, LIKUDITAS, INTENSITAS PERSEDIAAN TERHADAP AGRESIVITAS PAJAK
}

\author{
Laras Pangesti ${ }^{1}$, Endang Masitoh $\mathbf{W}^{2}$, dan Anita Wijayanti ${ }^{3}$ \\ ${ }^{1}$ Universitas Islam Batik Surakarta \\ ${ }^{2}$ Universitas Islam Batik Surakarta \\ ${ }^{3}$ Universitas Islam Batik Surakarta \\ Email Corespondent : laraslaras048@gmail.com,yunmasitoh@yahoo.com,itax_solo@yahoo.com
}

\begin{abstract}
This study aims to determine the effect of Debt Policy, Liquidity, Inventory Intensity on Tax Aggressiveness. With secondary data from the financial statements of mining sector companies listed on the Stock Exchange in 2016-2018, using 40 respondents and purposive sampling methods, namely (1) Manufacturing Companies that have been listed on the Indonesia Stock Exchange that have submitted financial reports as of 31 December according to the study period. (2) Companies that submit complete data. (3) Using the Dollar in its financial reporting. (4) Has an ETR value between 0-1. (5) Companies that have never suffered losses during the study period. The analysis technique uses multiple linear regression with SPSS version 18. The results of this study indicate (1) Debt Policy has an effect and significant effect on tax aggressiveness, (2) Liquidity has no effect on tax aggressiveness, 2) Inventory intensity has no effect on tax aggressiveness. Benefits of research, (1) For practitioners, input for investors in investing in the capital market is also a reference to make a healthy company with this research. (2) For Theoretical, Add insight into Debt Policy, Liquidity, Inventory Intensity and Tax Aggressiveness.
\end{abstract}

Keywords : Policy; Debt; Liquidity; Intensity; Inventory; Aggressiveness

\begin{abstract}
Abstrak: Penelitian ini memiliki tujuan untuk mengetahui pengaruh Kebijakan Utang, Likuiditas, Intensitas Persediaan terhadap Agresivitas Pajak. Dengan data sekunder dari laporan keuangan perusahaan sektor pertambangan yang terdaftar di BEI tahun 2016-2018, menggunakan 40 responden dan metode purposive sampling yaitu (1) Perusahaan Manufaktur yang telah terdaftar di Bursa Efek Indonesia yang telah menyampaikan laporan keuangan per 31 Desember sesuai periode penelitian. (2) Perusahaan yang menyampaikan datanya secara lengkap. (3) Menggunakan Mata uang Dollar dalam pelaporan keuangannya. (4) Memiliki nilai ETR antara 0-1. (5) Perusahaan yang tidak pernah mengalami kerugian selama periode penelitian. Teknik analisis menggunakan regresi linier berganda dengan program SPSS versi 18. Hasil dari penelitian ini menunjukkan (1) Kebijakan Utang berpengaruh dan signifikan terhadap agresivitas pajak, (2) Likuiditas tidak berpengaruh terhadap agresivitas pajak, 2) Intensitas Persediaan tidak berpengaruh terhadap agresivitas pajak. Manfaat penelitian, (1) Bagi Praktisi, masukan untuk investor dalam berinvestasi di pasar modal juga acuan untuk menjadikan perusahan yang sehat dengan adanya penelitian ini. (2) Bagi Teoritis, Menambah wawasan tentang Kebijakan Utang, Likuiditas, Intensitas Persediaan serta Agresivitas Pajak.
\end{abstract}

Keywords : Kebijakan, Utang, Likuiditas, Intesitas, Persediaan, Agresivitas 


\section{PENDAHULUAN}

Besarnya kontribusi pajak dalam mendanai sebagian besar pembangungan negara untuk mendorong pertumbuhan ekonomi nasional menjadikan pajak sebagai tulang punggung negara. Selain itu, pajak telah menjadi simbol kemandirian Indonesia dalam pelaksanaan pemerintahan yang berdaulat. Indonesia sendiri dihadapkan dengan permasalahan perpajakan diantaranya rendahnya rasio pajak yang dimiliki oleh Indonesia.

Dilihat dari data diatas penerimaan pajak di Indonesia belum mampu mencapai target yang diharapkan. Meskipun penerimaan pajak tumbuh positif, tetapi sektor industri yang berkontribusi $20.8 \%$ terhadap pajak justru tumbuh negatif. Penerimaan sektor manufaktur tercatat 16.77 triliun atau turun $16.2 \%$ year on year. Penurunan ini dikarenakan restitusi dipercepat yang melonjak Januari 2019. Bila dilihat jumlah restitusi PPN yang dilakukan sebesar 16.4 Triliun atau tumbuh $40.66 \%$ year on year. Sedangkan Januari 2018 nominal PPN hanya sebesar 11.6 Triliun. Ketidakmampuan Pemerintah merealisasikan target tersebut menimbulkan pertanyaan "Adakah pungutan yang dilakukan belum berjalan maxsimal ataukah ada tindakan penghindaran pajak dari wajib pajak.

\section{TINJAUAN PUSTAKA}

\section{Teori Agensi}

Arfan Ikhsan dan Herkulanus Bambang Suprasto menjelaskan dalam buku Teori Akuntansi dan Riset Multiparadigma (2008) bahwa Agensi teori bertujuan untuk menyelesaikan masalah. Pertama masalah agensi yang muncul ketika adanya konflik tujuan antara principal dan agent serta kesulitan principal melakukan verifikasi pekerjaan agent. Kedua, masalah pembagian risiko yang muncul ketika prinsipal dan agen memiliki perilaku yang berbeda terhadap risiko. Secara keseluruhan, agency theory adalah hubungan struktur agensi dari prinsipal dan agent yang mengikat janji berperilaku kooperatif, tetapi dengan tujuan yang berbeda dan perilaku menghadapi risiko yang berbeda.

\section{Kebijakan Utang}

Kebijakan utang atau debt policy merupakan bagian dari kebijakan pendanaan yang memiliki peran signifikan terhadap tingkat penghindaran pajak perusahaan seperti dalam menentukan pembiayaan perusahaan dalam bentuk utang (Zahirah, 2017). Kebijakan utang berbicara mengenai seberapa jauh perusahaan menggunakan pendanaan utang dalam rangka untuk membiayai aktivitas operasional perusahaan (Pratiwi dan Mertha, 2017). Indikator yang digunakan untuk meramalkan prospek suatu perusahaan yaitu dengan memperhatikan tingkat pertumbuhan profit. Indikator yang digunakan untuk menilai tingkat profitabilitas antara lain Return On
Asset (ROA). ROA mengukur kemampuan perusahaan menghasilkan laba dengan menggunakan total asset (kekayaan) yang dimiliki perusahaan setelah disesuaikan dengan biaya - biaya untuk mendanai asset tersebut (Hanafi et al, 2009).

\section{Likuiditas}

Rasio likuiditas yang dapat dijadikan mengukur kemampuan perusahaan menurut Kasmir (2014:134). Dalam penelitian ini menggunakan Rasio Lancar atau Current Ratio berfungsi untuk mengetahui kemampuan perusahaan dalam membayar kewajiban jangka pendek atau utang jangka pendek yang akan jatuh tempo pada saat ditagih secara keseluruhan. Rasio ini digunakan untuk mengukur tingkat keamanan (margin of safety) suatu perusahaan.

\section{Intensitas Persediaan}

Persediaan perusahaan atau inventory intensity bagian dari aset lancar perusahaan yang dipergunakan untuk memenuhi permintaan dan operasional perusahaan dalam jangka panjang. Biaya tambahan yang timbul akibat investasi perusahaan pada persediaan harus dikeluarkan dari biaya persediaan dan diakui sebagai biaya dalam periode terjadinya biaya. Intensitas persediaan adalah menandakan besarnya perputaran persediaan yang terjadi selama periode berjalan

\section{Pengaruh Kebijakan Utang terhadap Agresivitas Pajak}

Penelitian yang dilakukan oleh Irsan Lubis et.al (2018) mengemukan Kebijakan Utang berpengaruh signifikan terhadap agresifitas pajak. Hasil penelitian ini sejalan dengan dengan Hartadinata dan Tjaraka (2013) dan Atari (2016) membuktikan bahwa kebijakan utang berpengaruh positif dan signifikan terhadap agresivitas pajak karena nilai rasio tingkat utang yang semakin tinggi disebabkan oleh utang kepada pihak ketiga lebih tinggi daripada utang kepada pemegang saham, sehingga beban bunga akan lebih besar dan dapat mengurangi beban pajak perusahaan. H1 : Kebijakan Utang berpengaruh terhadap Agresivitas Pajak

\section{Pengaruh Likuiditas terhadap Agresivitas Pajak}

Penelitian yang dilakukan oleh Ida Bagus Putu Fajar Adisamartha dan Naniek Noviari (2015) mengemukan bahwa Likuiditas perusahaan berpengaruh terhadap tingkat agresivitas wajib pajak badan. Semakin tinggi tingkat likuiditas, maka perusahaan lebih agresif dalam menangani beban pajaknya karena likuiditas yang tinggi akan berpengaruh pada tingkat laba yang tinggi. Hasil penelitian ini sejalan dengan dengan Suyanto (2012) dan Yusriwati (2012) membuktikan bahwa semakin 
tinggi rasio likuiditas perusahaan, maka tindakan untuk mengurangi laba akan makin tinggi dengan alasan menghindari beban pajak yang lebih tinggi. Semakin tinggi rasio likuiditas maka akan berbanding positif dengan tingkat agresivitas pajak perusahaan.

$\mathrm{H} 2$ : Likuiditas berpengaruh terhadap Agresivitas Pajak

\section{Pengaruh Intensitas Persediaan terhadap Agresivitas Pajak}

Penelitian yang dilakukan oleh Ida Bagus Putu Fajar Adisamartha dan Naniek Noviari (2015) mengemukan bahwa Intensitas Persediaan berpengaruh pada tingkat agresivitas wajib pajak badan. Intensitas persediaan yang tinggi akan meningkatkan laba bersih perusahaan karena biaya-biaya yang terkandung dalam persediaan mampu diefisienkan. Perusahaan akan meningkatkan persediaan akhir guna mengurangi intensitas persediaan dan meningkatkan biaya-biaya yang terkandung dalam perusahaan untuk mengurangi laba bersih dan berkurangnya beban pajak.

H3 : Intensitas Persediaan berpengaruh terhadap Agresivitas Pajak

\section{METODE PENELITIAN}

\section{Data}

Populasi dalam penelitian ini adalah perusahaan sektor pertambangan yang terdaftar di Bursa Efek Indonesia dalam kurun waktu 2016-2018. Pemilihan sampel dalam penelitian ini menggunakan teknik purposive sampling. Data yang diambil yaitu perusahaan sektor pertambangan sejumlah 40 .

\section{Operasionalisasi Variabel \\ Variabel Dependen}

Variabel Dependen dalam penelitian ini adalah Agresivitas Pajak. Agresivitas pajak adalah tindakan yang didesain untuk mengurangi Penghasilan Kena Pajak (PKP) dengan perencanaan pajak yang sesuai. Tarif pajak efektif yang rendah menggambarkan tingkat agresivitas pajak yang tinggi dan demikian juga sebaliknya. Dalam penelitian ini agresivitas pajak diproksikan dengan Effective Tax Rate (ETR), menurut Lanis (2012) menyatakan bahwa ETR merupakan proksi yang paling banyak digunakan pada penelitian sebelumnya dengan indikator bahwa adanya agresivitas pajak apabila memiliki ETR yang mendekati 0 . Semakin rendah nilai ETR yang dimiliki perusahaan, maka semakin tinggi tingkat agresivitas pajak. ETR dapat dihitung denganrumus sebagai berikut :

$$
E T R=\frac{\text { Beban Pajak Penghasilan }}{\text { Total Laba Sebelum Pajak }}
$$

\section{Kebijakan Utang}

Kebijakan hutang merupakan kebijakan pendanaan yang dilakukan oleh pihak manajemen perusahaan dalam rangka memperoleh sumber pendanaan untuk membiayai aktivitas operasional perusahaan (Pratiwi dan Mertha, 2017). Dalam penelitian ini kebijakan utang diproksikan menggunakan Debt to Asset Ratio (DAR) karena melalui rasio DAR dapat diketahui seberapa besar jumlah perolehan asset perusahaan yang didanai melalui utang, dan seberapa besar kemampuan perusahaan untuk menyelesaikan segala kewajiban dengan aset yang dimilikinya. DAR dapat dihitung dengan :

$$
D A R=\frac{\text { Total Utang }}{\text { Total Asset }}
$$

\section{Likuiditas}

Likuiditas yaitu ukuran dalam menilai kemampuan sebuah perusahaan untuk memenuhi kewajiban jangka pendek dan kemampuan perusahaan dalam menghadapi kondisi mendesak yang memerlukan dana (Kieso et al, 2009:788). Rasio yang digunakan ialah Rasio lancar karena sesuai untuk mengukur kemampuan jangka pendek perusahaan. Rasio likuiditas diukur dengan :

$$
C R=\frac{\text { Aset Lancar }}{\text { Kewajiban Lancar }}
$$

\section{Intensitas Persediaan}

Intensitas Persediaan menandakan besarnya perputaran persediaan yang terjadi selama periode berjalan. Rasio yang menunjukkan keefektifan investasi perusahaan dalam persediaan tersebut berputar dalam satu periode tertentu yang digunakan untuk mengevaluasi tingkat persediaan berbanding volume usaha. Intensitas Persediaan diperoleh dengan membandingkan Harga Pokok Penjualan dengan jumlah persediaan akhir perusahaan (Derashid dan Zhang, 2013).

$$
\text { INVINT }=\frac{\text { Harga Pokok Penjualan }}{\text { Total Persediaan Akhir }}
$$

\section{Metode Analisis}

Penelitian ini menggunakan analisis regresi linier berganda dengan model persamaan sebagai berikut :

$$
\mathrm{Y}=\alpha+\beta 1 \mathrm{DAR}+\beta 2 \mathrm{CR}+\beta 3 \mathrm{INVINT}+\mathrm{e}
$$

\section{Keterangan :}

\section{Variabel Independen}




$\begin{array}{ll}\mathrm{Y} & =\text { Agresivitas Pajak } \\ \mathrm{A} & =\text { Konstanta } \\ \mathrm{DAR} & =\text { Kebijakan Utang } \\ \mathrm{CR} & =\text { Likuiditas } \\ \text { INVINT } & =\text { Intensitas Persediaan } \\ \beta 1 \beta 2 \beta 3 & =\text { Koefisien regresi parsial } \\ \mathrm{E} & =\text { Error }\end{array}$

\section{HASIL DAN PEMBAHASAN}

Sebelum data dianalisis, data tersebut telah dilakukan pengujian kenormalan data. Berdasarkan hasil uji normalitas, didapat bahwa data terdistribusi secara normal. Hasil analisis regresi linier terhadap variabel penelitian menunjukkan hasil sebagai berikut pada Tabel berikut:

Tabel 1 Uji Regresi Linier Berganda

\begin{tabular}{cc}
\hline Model & Unstandardized Coefficients \\
& $\mathrm{B}$ \\
\hline (Constant) &, 232 \\
$D A R$ &, 1951 \\
$C R$ &, 006 \\
INVINT &, 000 \\
Sumber : Hasil olah data (2019)
\end{tabular}

Berdasarkan hasil analisis pada tabel 7 maka persamaan regresi linier berganda adalah sebagai berikut :

$\mathrm{ETR}=0,232+0,195 \mathrm{DAR}+0,006 \mathrm{CR}+0,000$

INVINT

a. Nilai konstanta sebesar 0,232 yang menyatakan bahwa Kebijakan Utang, Likuiditas, dan Intensitas Persediaan nilainya 0, maka Agresivitas Pajak nilainya 0,232

b. Variabel Kebijakan Utang memiliki koefisien regresi dengan arah positif sebesar 0,195. Hal ini berkaitan bahwa setiap kenaikan satu persen dari variabel Kebijakan Utang akan menyebabkan variabel Agresivitas pajak mengalami kenaikan sebesar 0,195 persen dengan asumsi variabel independen lainnya memiliki nilai nol atau konstan.

c. Variabel likuiditas memiliki koefisien regresi dengan arah positif sebesar 0,006. Hal ini berkaitan bahwa setiap kenaikan satu persen dari variabel likuiditas akan menyebabkan variabel agresivitas pajak mengalami peningkatan sebesar 0,006 persen dengan asumsi variabel independen lainnya memiliki nilai nol atau konstan.

Variabel intensitas persediaan memiliki koefisien regresi dengan arah positif sebesar 0,000 . Hal ini berkaitan bahwa setiap kenaikan satu persen dari variabel intensitas persediaan akan menyebabkan variabel agresivitas pajak konstan atau tidak ada kenaikan dengan asumsi variabel independen lainnya memiliki nilai nol atau konstan.

Tabel 2 Uji Kelayakan Model (Uji F)

\begin{tabular}{lcllll}
\hline $\begin{array}{c}\text { Mod } \\
\text { el }\end{array}$ & $\begin{array}{c}\text { F } \\
\text { hitu- } \\
\text { ng }\end{array}$ & $\begin{array}{c}\text { F } \\
\text { tabel }\end{array}$ & Sig & Std & Ket \\
\hline $\begin{array}{l}\text { Regres } \\
\text { sion }\end{array}$ & 3,374 & 2,86 & 0,02 & $<0,05$ & $\begin{array}{l}\text { Model } \\
\text { layak }\end{array}$ \\
& & 6 & 9 & & layk \\
\hline
\end{tabular}

Sumber : Hasil olah data (2019)

Tabel 3 Uji Hipotesis (Uji t)

\begin{tabular}{lccccc}
\hline $\begin{array}{c}\text { Varia } \\
\text {-bel }\end{array}$ & $\begin{array}{c}\mathrm{t} \\
\text { hitu } \\
\text {-ng }\end{array}$ & $\begin{array}{c}\mathrm{t} \\
\text { tabel }\end{array}$ & Sig & Standar & Keterangan \\
\hline DAR & 2,563 & 1,688 & 0,015 & $<0,05$ & H1 diterima \\
CR & 0,458 & 1,688 & 0,649 & $<0,05$ & H2 ditolak \\
& & & & & \\
INVINT & $-0,41(1,688$ & 0,684 & $<0,05$ & H3 \\
& & & & ditolak
\end{tabular}

Sumber : Hasil olah data (2019)

Berdasarkan hasil uji hipotesis pada table 10, dapat dipaparkan sebagai berikut :

a. Hasil uji t dapat dilihat pada tabel di atas bahwa nilai signifikansi dari variabel bebas kebijakan utang sebesar 0,015 memiliki nilai yang lebih kecil dari 0,05 . Selain itu, Nilai t hitung dari variabel kebijakan utang adalah 2,563 dengan besaran nilai $\mathrm{t}$ tabel 1,688 . Hal ini berarti $\mathrm{t}$ hitung $>\mathrm{t}$ tabel yaitu $2.523>1.688$ yang artinya kebijakan utang berpengaruh positif terhadap agresivitas pajak.

b. Hasil uji t dapat dilihat pada tabel di atas bahwa nilai signifikansi dari variabel bebas likuiditas sebesar 0,649 memiliki nilai yang lebih besar dari 0,05 . Selain itu, Nilai t hitung dari variabel likuiditas adalah 0,458 dengan besaran nilai $\mathrm{t}$ tabel 2,017. Hal ini berarti $\mathrm{t}$ hitung $<\mathrm{t}$ tabel yaitu $0,649<1.688$ yang artinya likuiditas tidak berpengaruh terhadap agresivitas pajak.

c. Hasil uji t dapat dilihat pada tabel di atas bahwa nilai signifikansi dari variabel bebas intensitas persediaan sebesar 0,684 memiliki nilai yang lebih besar dari 0,05. Selain itu, Nilai t hitung dari variabel intensitas persediaan adalah $-0,410$ dengan besaran nilai $t$ tabel 1.688. Hal ini berarti $\mathrm{t}$ hitung $<\mathrm{t}$ tabel yaitu $-0,410<1.688$ yang artinya intensitas persediaan tidak berpengaruh terhadap agresivitas pajak. 


\section{PENUTUP}

\section{Kesimpulan}

Penelitian ini bertujuan menguji pengaruh kebijakan utang, likuiditas dan intensitas persediaan terhadap agresivitas pajak pada perusahaan sektor pertambangan yang terdaftar di BEI tahun 2016 - 2018. Populasi dalam penelitian ini adalah perusahaan pertambangan di Bursa Efek Indonesia (BEI). Pengambilan sampel dalam penelitian ini dilakukan dengan metode purposive sampling dan menggunakan teknik analisis regresi linier berganda dengan jumlah observasi data sebanyak 40.

Hipotesis 1 menyatakan bahwa kebijakan utang (DAR) berpengaruh terhadap agresivitas pajak. Penelitian ini sejalan dengan Irsan Lubis, Suryani, dan Firli Anggraeni (2018) dan Jeane Atari (2016). Hipotesis 2 menyatakan bahwa likuiditas (CR) tidak berpengaruh terhadap agresivitas pajak. Penelitian ini sejalan dengan penelitian Irvan Tiaras dan Henryanto (2015). Namun berbanding terbalik dengan penelitian yang dilakukan oleh Ida Bagus Putu Fajar Adisamartha dan Naniek Noviari (2015). Hipotesis 3 menyatakan bahwa intensitas persediaan (INTIVT) tidak berpengaruh terhadap agresivitas pajak. Penelitian ini sejalan dengan penelitian oleh Putu Ayu Seri Andhari dan I Made Sukartha (2017) dan Vicky Amelia (2015). Namun berbanding terbalik dengan penelitian yang dilakukan oleh Ioannis Stamatopoulos et.al (2019) dan Georgeta Vintilă et.al (2018).

Hasil penelitian ini menyimpulkan bahwa (1) Jika kebijakan utang semakin besar maka semakin besar beban bunga yang dibayarkan perusahaan, sehingga semakin tinggi agresivitas pajak perusahaan. (2) Semakin meningkatnya rasio likuiditas, tidak berpengaruh signifikan terhadap penurunan laba perusahaan, sehingga tidak berpengaruh terhadap praktik agresivitas pajak perusahaan. (3) Setiap kenaikan intensitas persediaan dalam suatu perusahaan tidak menunjukkan penurunan beban pajak penghasilan perusahaan, sehingga biaya tambahan yang timbul akibat investasi perusahaan pada persediaan tidak berpengaruh signifikan terhadap penurunan laba bersih.

\section{Saran}

Bagi peneliti lain yang tertarik mengambil topik mengenai variabel yang mempengaruhi agresivitas pajak disarankan untuk menambah tahun penelitian dan menggunakan variasi penghitungan yang berbeda dengan penelitian ini agar tingkat ketelitian dan tingkat kepastian semakin besar.

Untuk penelitian selanjutnya disarankan dapat menambah perusahaan yang akan dijadikan populasi ataupun sampel penelitian dan tidak hanya terbatas pada sektor pertambangan saja. Dan juga menambah variabel yang berpengaruh terhadap agresivitas pajak seperti ukuran perusahaan, leverage, intensitas modal, dan lain sebagainya. 


\section{REFERENSI}

Adisamartha, I. B. (2015). Pengaruh Likuiditas, Leverage, Intensitas Persediaan dan Intensitas Aset Tetap pada Tingkat Agresivitas Pajak. E-Jurnal Akuntansi Universitas Udayana.

Christopher S Armstrong, J. L. (2012). The Incentive for Tax Planning. Journal of Accounting and Economics 53, 391-411.

Derashid, C. d. (2003). Effective tax rates and the "industrial" policy hypotesis: Evidence from Malaysia. Journal of International Accounting \& Taxation, 45-62.

Georgeta Vintilă, Ş. C. (2018). Study of Effective Corporate Tax Rate and Its Influential Factors: Empirical Evidence from Emerging European Markets. Emerging Markets Finance and Trade, 571-590.

Ghozali, I. (2005). Aplikasi Analisis Multivariate dengan Program IBM SPSS 20. Semarang: Penerbit Undip.

Gujarati, D. N. (2006). Ekonometrika Dasar. Jakarta: Penerbit Erlangga.

Handayani, S. d. (2011). Faktor-Faktor Yang Mempengaruhi Struktur Modal Pada Perusahaan Publik Sektor Manufaktur . Jurnal Bisnis \& Akuntansi, 39-56.

Hanlon, M. a. (2010 ). A review of Tax Research. Journal of Accounting and Economics 50, 127-178.

Hartadinata, H. T. (2013). Analisis Pengaruh Kepemilikan Manajerial, Kebijakan Hutang, dan Ukuran Perusahaan Manufaktur di Bursa Efek Indonesia. Jurnal Ekonomi dan Bisnis, 48-59.

$i d x$. (2020). Retrieved from http://www.idx.com

idx. (n.d.). www.idx.com.

Ioannis Stamatopoulos, S. H. (2019). Explaining corporate effective tax rates: Evidence from Greece. Economic Analysis and Policy, 236-254.

Jaewoo Kim, P. Q. (2016). Managerial Ownership and Tax Planning: Evidence from Stock Ownership Plans. Journal of Accounting, 1-41.

Jensen, M. a. (1976). "Theory of The Firm: Managerial Behavior, Agency Costs, and Ownership Structure". Journal of Financial Economics, 3, 272-296.

Kasmir. (2014). Analisis Laporan Keuangan. Jakarta: Raja Grafindo Persada.

Kieso, D. E. (2011). Accounting Principles. Hoboken: John Wiley \& Sons, In.

Lanis, R. a. (2007). Determinants of Variability in Corporate Effective Tax Rate and Tax Reform : Evidence from Australia. . Journal of Accounting and Public Policy 26, 689-704.

Liansheng Wu, Y. W. (2007). State ownership, tax status and size effect of effective tax rate in China. Journal Accounting and Business Research, 97-144.

Mangonting, J. H. (2014). Pengaruh Struktur Kepemilikan Dan Karakteristik Dewan Terhadap Agresivitas Pajak. Tax \& Accounting Review.

Mardiyati, U. (2012). Pengaruh Kebijakan Dividen, Kebijakan Hutang dan Profitabilitas Terhadap Nilai Perusahaan Manufaktur yang Terdaftar di Bursa Efek Indonesia (BEI) Periode 2005-2010. Jurnal Riset Manajemen Sains Indonesia (JRMSI).

Martínez-Arias, E. F.-R. (2014). Determinants of the Effective Tax Rate in the BRIC Countries. Emerging Markets Finance and Trade, 214-228.

Martini, M. R. (September 2014). Ridha, Muhamad., \& Martini, Dwi. 2014. Analisis terhadap Agresivitas pajak, Agresivitas Pelaporan Keuangan, dan Tata Kelola Perusahaan di Indonesia. . Simposium Nasional Akuntansi XVII Mataram, (pp. 24-27 ). Lombok.

Mary Frank, L. L. (2009). Tax Reporting Aggressiveness and Its Relation to Aggressive Financial Reporting. The Accounting Review, 467-496.

Mertha, N. P. (2017, Agustus). Pengaruh Kebijakan Hutang dan Profitabilitas Pada Nilai Perusahaan dengan Kebijakan Dividen sebagai Variabel Pemoderasi. E-Jurnal Akuntansi Universitas Udayana, 20 .

Munawir. (2010). Analisa Laporan Keuangan, cetakan ke-15. Yogyakarta: Liberty.

Putri Popi Ayuni, Z. Z. (2014). Pengaruh Mekanisme Corporate Governance dan Pengungkapan Corporate Social Responsibility terhadap Tax Avoidance. Jurnal Akuntansi, 1-15.

Rustiarini, N. W. (2009). Pengaruh Struktur Kepemilikan Saham Pada Pengungkapan Corporate Social Responsibility. Simposium Nasional Akuntansi.

Sugiyono. (2012). Memahami Penelitian Kuantitatif Kualitatif. . Bandung: Alfabeta.

Suprasto, A. I. (2008). Buku Teori Akuntansi dan Riset Multiparadigma. 
Suyanto, K. D. (2012). "Likuiditas, leverage, komisris independen, dan manajemen laba terhadap agresivitas pajak perusahaan”. Jurnal Keuangan dan Perbankan, 167-177 .

Swenson, J. E. (2007). Strategi Business Tax Planning. John Wiley \& Sons.

Yusriwati. (2012). Pengaruh Likuiditas, Solvabilitas, dan Rentabilitas Terhadap Laba pada PT. UNILEVER INDONESIA. Jurnal Akuntansi dan Keuangan-Edisi 1: Januari-Juni 2012.

Zahirah, A. (2017). Pengaruh Leverage, Kepemilikan Institusional, Kepemilikan Manajerial dan Ukuran Perusahaan terhadap Penghindaran Pajak. JOM Fekon, 4.

http://www.idx.co.id 